\title{
Papers
}

\section{Pyrrhic victory? The unintended consequence of the Pensions Act 2004}

Received (in revised form): 14th February 2007

\author{
Alistair Byrne* \\ is a fellow of the Pensions Institute and a lecturer in Finance at the University of Strathclyde in Glasgow. \\ Debbie Harrison \\ is a senior visiting fellow of the Pensions Institute and a financial journalist.

\section{Bill Rhodes} \\ is a non-executive director of Pendragon plc and a pension scheme trustee.

\section{David Blake} \\ is the Director of the Pensions Institute and Professor of Pensions Economics at Cass Business School.
}

\begin{abstract}
The UK's 2004 Pensions Act is a far-reaching piece of legislation, with significant implications for the occupational pensions marketplace. The Act is intended to improve the governance of pension schemes and increase the security of the members' accrued benefits. Our research, however, suggests that it will have serious and adverse unintended consequences. The most significant of these is to undermine occupational pension provision by placing an increased burden on sponsoring employers, whose involvement in pension provision is on a voluntary basis. Pensions (2007) 12, 59-67. doi:10.1057/palgrave.pm.5950048
\end{abstract}

Keywords: Pensions Act 2004, regulation, pension scheme closure, Pension Protection Fund

\section{Introduction}

'There is no point in having the best regulation in the world if there are no schemes left to regulate.' [Pensions Lawyer]

The UK's Pensions Act 2004 ('the Act') is a wide-ranging piece of legislation with significant consequences for the country's occupational pensions marketplace ${ }^{1}$. The government introduced the Act to ensure that occupational pension schemes are sufficiently well funded to meet their liabilities to members. At present, most defined benefit (DB) schemes register a deficit and in a significant minority

*Correspondence: Alistair Byrne, Lecturer in Finance, University of Strathclyde, 100 Cathedral Street, G4 OLN, Glasgow

Tel: 0141548 3939, Fax: 01415523547 ,

E-mail: alistair.byrne@strath.ac.uk of cases this is large relative to the sponsoring company's market capitalisation.

The Act introduces a framework for restoring DB pension scheme solvency over a short recovery period. Our research suggests that this will risk alienating the voluntary corporate sponsors upon which occupational pensions in the UK rely, by reducing their ability to manage this significant business risk. The historic alignment of the interests of pension scheme trustees and the sponsoring employer is under threat.

The vast majority of pensions professionals we spoke to warned that unless trustees and the new Pensions Regulator can structure the recovery process with a clear focus on the longterm implications of their actions for the financial health of the sponsoring companies, employers 
would respond by closing DB schemes to future accrual by existing members. National Association of Pensions Funds statistics (private correspondence) indicate that currently 70 per cent of the UK's 20,000 occupational pension schemes are closed to new members and 15 per cent are also closed to future accrual by existing members. Many of our respondents suggested that the majority of schemes could be closed to future accrual within five-to-ten years.

Our research indicates that in the place of a final salary-linked pension scheme, most companies will introduce contract-based defined contribution (DC) schemes - a trend already well under way. Our findings also suggest that companies with existing trust-based occupational DC schemes are looking to move to a contract basis, reflecting their desire to withdraw from the complexity of trust-based benefits. In the light of these findings, it seems likely that in future the main burden of private pension provision will fall directly on individuals, who arguably are ill equipped to manage the associated investment and longevity risks. The burden will also fall on the taxpayer, who ultimately will be forced to pick up the bill for pension scheme support when employers become insolvent, and for state retirement benefits when DC arrangements fail to deliver adequate private pensions.

Our research was produced using information from interviews conducted over the summer of 2005 with over 70 people, including actuarial and investment consultants, accountants, pensions lawyers, asset managers, investment bankers, pensions managers and trustees. What is particularly significant in the analysis is how many of the most striking views are consistently held across all the participating groups. The vast majority of the respondents think that the well-intentioned measures in the Act will have a high price in terms of damaging future provision of occupational pension benefits.

Box 1 sets out the key provisions of the Act, while in the following sections we present the results of our interviews with professionals involved in occupational pension provision in the UK. We identify the respondents only by category and their comments are in italics. This paper concentrates on issues around scheme funding and the relationship between trustees and sponsoring employers. ${ }^{2}$

\section{Pension scheme funding and conflicts of interest}

The Act sets out a statutory funding objective (SFO) that pension schemes must meet, and requires the trustees to prepare a statement of funding principles (SFP) designed to meet the SFO. The new Pensions Regulator's Code of Practice 'Funding Defined Benefits' ${ }^{3}$ sets out its expectation that full funding should be achieved 'as soon as practicable'.

Almost all respondents held the view that the new requirements create a more adversarial relationship between trustees and corporate sponsors in terms of negotiating funding of the pension scheme. Respondents felt that the Act fails to recognise that the interests of trustees as employees and scheme beneficiaries and the sponsor are well aligned in most cases.
'The 1995 Act also recognises this conflict and trust law has done so for hundreds of years. Conflict is good - it gets different views out on the table and stimulates discussion. The issue has always been to spot when a conflict becomes unmanageable. What has changed is that the new Act appears to positively encourage conflict rather than conciliation. The Regulator is encouraging trustees to take an aggressive and confrontational approach in negotiations with the company.' [Pensions lawyer]

There was concern among some respondents as to whether trustees would use their new powers prudently. Effectively, trustees have the power to push a company into insolvency if they can demonstrate that this is in the best interests of the pension scheme. The Regulator can back them in this approach.

\footnotetext{
'Trustees need to recognise the business strains that will arise if they insist on a very tough recovery schedule. Trustees need to understand corporate structures and corporate financing. This has not been a traditional area of trustee knowledge.' [Accountant]
}

Trustees now also need to understand much more clearly the strength of the covenant they have from the sponsoring employer. The strength 


\section{Pensions Regulator}

The Act established a new Pensions Regulator, which is intended to be more proactive than its predecessor, the Occupational Pensions Regulatory Authority.

\section{Statutory Funding Requirement}

Every scheme is subject to a requirement - the statutory funding objective (SFO) - that it must have sufficient and appropriate assets to cover its liabilities. The trustees must maintain a written statement of their policy for securing that the SFO is met. If the SFO is not met, the trustees must prepare a recovery plan setting out the steps to be taken to meet the SFO and the period within which that is to be achieved.

\section{Contribution notices and Clearance}

The Pensions Regulator may issue a notice to a person stating that the person is under a liability to pay a specified sum into the pension scheme. The Regulator may issue a contribution notice where it is of the opinion that the person was party to an act or a failure to act the purpose of which was to prevent the recovery of the pension debt from the employer.

An application may be made to the Regulator for the issue of a clearance statement that, in its opinion, the applicant would not be subject to a contribution notice in respect of a certain act. A clearance statement binds the Regulator in relation to the exercise of the power to issue a contribution notice unless the circumstances that give rise to the contribution notice are materially different to the circumstances described in the application.

\section{Pension Protection Fund}

The Act established the Pensions Protection Fund (PPF), which is designed to provide compensation to pension scheme members where their employer becomes insolvent and the pension scheme is insufficiently funded to meet the accrued pension promises. The PPF compensation pays pensions in full for existing pensioners and up to 90 per cent of accrued benefits for members not yet retired, subject to a cap currently set at $£ 25,000$ per annum. The PPF is funded by a levy on pension schemes, 80 per cent of which comprises a risk-based levy assessed by reference to the size of the scheme's deficit and the likelihood of the employer becoming insolvent. The PPF has published an estimate of the total levy in 2006-2007 of $\mathcal{E} 300 \mathrm{~m}$, but more recently has acknowledged that other commentators estimate higher amounts.

of this covenant will depend on the company's ability to pay the required contributions, which in turn reflects its financial position. Put simply, if the company has a strong balance sheet and is making healthy profits, this implies a strong covenant; a weak balance sheet and poor profit forecasts implies the reverse.

The Pensions Regulator's guidance makes specific reference to the requirement for the length of the recovery plan to take into account 'the ability of the employer to pay contributions in accordance with the recovery plan'. ${ }^{3}$ There is a difficult balance to be struck.

\begin{abstract}
'The biggest issue is the strength of the employer's covenant, as this will dictate the period over which the trustees should aim to collect the deficit money. In theory, the poorer the covenant, the faster the recovery schedule, but this could actually push the employer into insolvency, which would be counter-productive.' [Pensions manager]
\end{abstract}

Almost all respondents thought that, as a result of the new approach to scheme funding, company directors serving as trustees faced potential conflicts of interest. A few thought the potential conflicts were a price worth paying for the knowledge and insight into the company's 
views that they brought to the trustee group. The vast majority of respondents anticipated that the era in which company directors could serve on trustee boards is, however, coming to an end, particularly in the case of finance directors, managing directors and chief executive officers.

Without exception, respondents said that the loss of company directors would significantly reduce the skill set of the trustee board, and would damage the information flow and the trustees' understanding of the company context and perspective. The Act provides no guidance on pension scheme governance in the event of company directors resigning from the trustee board. The loss of company executives as trustees will require new governance structures to ensure the continuation of a two-way flow of information between the company board and the trustees.

'I've seen schemes where there is no senior company trustee and they behave as though they are rudderless - there's no sense of direction without the company position and where the scheme fits in with the company's future.' [Consultant]

Several respondents suggested that company board members would still need to attend trustee meetings even if they were no longer trustees.

'A reasonable compromise might be where the company executives attend meetings as "visitors".' [Trustee]

'If I were the finance director, I would not want to be a trustee but I would demand a seat at the table. I'm the cheque book and my main concern is the governance of the board and risk control from the company's perspective.' [Asset manager]

Smaller companies, in particular, may face problems in finding people outside the board who have the necessary knowledge and ability to be trustees.

\section{Regulatory clearance procedures}

The Pensions Regulator runs a clearance procedure whereby companies that engage in corporate finance transactions that could be construed as counter to the interests of the pension scheme members, for example transferring assets that could otherwise be used to fund the scheme, can apply for a ruling from the Regulator to confirm its opinion that the transaction is for bona fide purposes. In the absence of this clearance, the Regulator has the power to challenge transactions after the fact, and parties to them, such as directors or other group companies, may become liable to support pension schemes in deficit.

Full funding measured on the basis used in Financial Reporting Standard 17 (FRS17) was widely considered to be the key benchmark the Regulator is using at present to determine clearance applications.

'The Regulator seems to be taking FRS17 solvency as the basis for negotiation. If a scheme falls below this, then the Regulator will use clearance as an opportunity to force the employer to improve scheme funding.' [Pensions lawyer]

'It looks like getting to 100 per cent funding on FRS17 will get the Regulator off your back.' [Pensions manager]

The clearance procedures are regarded as a major change for trustees and one that is, on balance, positive for them and for scheme members in that the trustees can usually use the process to secure additional funds for the scheme.

'They [clearance procedures] will help trustees to help members, particularly in getting money into the scheme that might not otherwise have been contributed by the employer. Employers will have to "buy off" trustees now before corporate action.' [Consultant]

'I think the Regulator has said that in the first 50 cases to come for clearance, they have improved the position of the trustees in 48 of them.' [Insurance company]

The clearance procedures are also regarded as a major change to the corporate finance landscape, with important implications for companies and their advisers. The power to issue contribution notices and financial support directions, in effect to 'unpick' transactions that weaken the security of the pension scheme, creates new risks in corporate finance deals.

'Employers will find life more difficult when doing deals. The debt to the pension scheme has in the past been regarded as "softer" than any of the other debts. That 
seems to have been wrong and the new rules mean the pension debt will be properly taken into account in any deal.' [Trustee]

'It's having a big impact around here. Dealing with the pension scheme has turned into a prerequisite in $M \mathcal{E} A$ activity and also in transactions such as share buybacks. Previously, as long as the buyer and seller were happy, everything was ok. Now it gets much more attention.' [Investment bank]

Respondents report mixed reactions to clearance from employers. Companies were keen to have the assurance that they would not be subject to a subsequent contribution notice or financial support direction, but less enthusiastic about the process interfering in their business or requiring accelerated funding for the pension scheme in order to receive the clearance. Some respondents noted that, after an initial short period of enthusiasm, employers are becoming more reticent to seek clearance.

'Companies don't like the concept of clearance. They fear interference in the way the company runs. In practice its success will depend on the quality of the Regulator's staff.' [Consultant]

'They will perceive clearance as something that gets in the way of doing business, but it is not intended to assist the company, it is intended to help the scheme.' [Trustee]

There was also concern about the direct costs of clearance.

'In our experience clearance can cost between $£, 50,000$ and $£ 100,000$ to cover the legal, actuarial and independent accounting advice. Smaller and medium sized schemes are going to really struggle with that.' [Pensions lawyer]

Further, there was concern that clearance is not an absolute guarantee of immunity to future action.

'Clearance only provides contingent cover on the basis of information provided - and the Regulator asks for a short summary, so companies are strongly discouraged from sending in a huge report. But if they miss anything out or something emerges several years later, then clearance is invalid.' [Pensions lawyer]

One of the most important powers of the

Regulator is its ability to assess and hold responsible for the problems of a single company, the group as a whole and the parent. The Regulator's powers to pursue money owed by a parent or group may, however, be limited by geographical and political boundaries. For example, some respondents questioned whether the powers would be effective where the parent company is based outside the European Union. Furthermore, companies are unlikely to accept the Regulator's decisions to apply contribution notices and financial support directions without question.

'Companies will test the Regulator to the limits and will challenge decisions - it could take five years if it goes to the courts, during which time there will be a period of uncertainty. The Regulator has a wide armoury but some companies will try it on. While the Regulator has very effective resources and people at present will it be able to maintain these over the longer-term?' [Consultant]

\section{Pension Protection Fund}

The Act creates the PPF, which is designed to underwrite a proportion of the pension benefits of members of underfunded schemes where the employer becomes insolvent. Existing pensioners effectively receive their benefits in full, while members who were not retired at the point of insolvency receive 90 per cent of their benefits up to a cap, which is currently set at $£ 25,000$ per annum.

Respondents generally welcomed the concept of the PPF. Some also noted that it was politically attractive for the government to create it.

'The idea of PPF looked good on the front page of the Daily Mail. Somehow it has got to be made to work.' [Trustee]

Most of our professional respondents were, however, sceptical that it could work beyond the short term, at least as currently structured. Respondents agreed that the PPF could survive over the short term as it is currently financed, but as schemes close, mature and wind up the 'tax base' for the levy will shrink and the government and taxpayer will be forced to address controversial questions.

'It's a short-term fix and that's welcome. In the long term, the PPF is unstable. It faces a diminishing taxable franchise 
- that is, the number of available scheme to levy will fall

- and a rising liability.' [Pensions lawyer]

In the longer term, the PPF's viability will depend largely on the state of the economy.

'Beyond year ten it will start to get tricky - if not before - because it will be swamped. The PPF is so dependent on the economy - if we move into a downturn within the next five years then the PPF is going to be in big trouble because a lot of companies will go bust before they've had time to meet the recovery plan. If we go into a recession the PPF will be in danger of collapse - it will be forced into an increasingly unsustainable actuarial position.' [Consultant]

A key issue for many respondents was the effective cross-subsidy from well run schemes to weak or failing ones.

'Big plcs are very angry because they are picking up the can for disreputable companies - they are now having to pay the levy to bail out the rest.' [Accountant]

'The PPF is just a mechanism to transfer risk. You can move risk around and you can share it but you can't bring down the total level.' [Asset manager]

'In theory, the PPF can meet its objectives, but this is political. The government has effectively given the PPF the power of taxation.' [Consultant]

Some respondents thought that larger, well-funded schemes would take action to avoid the levy.

'The big multinationals will take their schemes offshore and avoid the levy. The forthcoming European directive says that a pension scheme can be in any EU country and still receive tax relief. No big scheme has moved out of the UK yet but it's going to happen.' [Pensions lawyer]

Most respondents thought the total levy would turn out to be higher than the initial indications of $f 300 \mathrm{~m}$ per year and that there might be need to cut the level of pension benefits protected by the PPF. Many felt the current annual pension cap of $£ 25,000$ was too generous.

'The monetary limits will have to come down or the levy be increased substantially.' [Consultant]

However, having introduced a comparatively low levy and high benefit guarantee it will be difficult for the government to make any significant changes without undermining confidence in the PPF. All the options bring political problems.

The Regulator has an important role to play in improving pension scheme funding and as a result reducing calls on the PPF.

'The Regulator is the gateway to PPF, therefore the success or otherwise of the PPF will depend on how that gateway is policed. The Regulator has to get money out of companies before the scheme goes to the PPF'. [Accountant]

Where an employer is in a weak financial position, it may be that it is unable to afford to fund the pension scheme deficit. At the extreme, requiring it to make good the deficit could force the employer into insolvency, costing current employees their jobs. The Regulator, therefore, faces a difficult balancing act between improving scheme funding and avoiding damaging going concern businesses.

We encountered very mixed views over the extent to which the Regulator and the PPF should take jobs into account.

'The Regulator will face situations where it has to decide whether to impose a level of contributions on the employer that may force the company into insolvency or to let the company continue at a lower contribution rate, knowing that it could still go bust and that this would land the PPF with an even bigger debt.' [Consultant]

'This is a very subjective issue. The best outcome could be to dilute pensions and protect jobs.' [Consultant]

'It's difficult - members age 29 will want job security, members age 59 will want pension security.' [Consultant]

Several respondents were concerned about the PPF's decision to accept the pension liabilities of the insolvent insurance broker Heath Lambert in return for 10 per cent of the equity of the new restructured group, Heath Lambert Holdings. The company argued that the deal allowed the business to be recapitalised and without new capital the pension liabilities would have fallen on PPF in any case. Our respondents argued that this is tantamount to state interference in the free market and would distort competition.

'The problem is how to go forward. The Heath Lambert precedent is a major concern. Will the Regulator's action 
give Heath Lambert a competitive edge - will competitors object?' [Investment bank]

'Why should a well-funded scheme have to pay a levy to support lesser-funded schemes and to perpetuate jobs in what is possibly a competitor company? This is politically motivated. Saving jobs is a legitimate objective, but should be funded by the taxpayer not by pension schemes.' [Trustee]

It remains to be seen whether taking equity stakes as a part of recapitalising businesses will be a standard approach for the PPF, or whether the circumstances of Heath Lambert render it a one off.

\section{The end of DB pension provision?}

There was near consensus among respondents that the changes introduced by the Act were viewed negatively by corporate sponsors and that closure of DB schemes was very much on the agenda. Respondents told us that employers and advisers believe that the legislation has converted what was originally a flexible and voluntary employer promise, where benefits could be reduced if necessary to accommodate economic conditions, to a legal guarantee. Companies that started their DB schemes with good intentions would never have done so if they knew they would be locked in to the guarantees the government now demands.

\section{'Employers already felt they had lost control over advisers and the investment strategy under the 1995 Act, now they feel they have lost control over the contribution rate.' [Consultant]}

'Increasingly, employers are being forced into an unfair position. They set up schemes in the past on a voluntary basis and between the 1995 and 2004 Acts they have been compelled to cede control of trustee boards to member nominated trustees.' [Consultant]

'Employers say they are losing their power to manage pension schemes that they started as a voluntary arrangement - because the government has changed the rules.' [Accountant]

The accelerated scheme funding required by the Act, the requirement to seek clearance for many corporate finance transactions and the requirement to pay the PPF levy all add significantly to the burden taken on by employers sponsoring DB pension schemes.

\section{Companies will close DB schemes to existing members}

Most respondents regarded closure of DB schemes to future accrual as an inevitable consequence of the existing deficits and the new rules that require the deficits to be recovered over relatively short time periods.

'We are already seeing more companies closing to future
accrual as a result of the Act.' [Consultant]

'Many would like to get out of DB pensions altogether and will do so if they possibly can.' [Investment bank]

While stopping offering DB to new recruits was a relatively easy step for many companies, stopping future accrual for existing members was thought to be a more difficult labour relations exercise. Nonetheless, most respondents still thought that it would happen in due course.

\footnotetext{
'Closure to future accrual has to be the next step. I'm surprised that hasn't happened more already. But, it is understandable that there is some reluctance to take a benefit away from current employees who already have it.' [Insurance company]
}

A key point raised by several respondents was that the government had failed to understand the fundamental difference between a voluntary pension promise, where discretion could be used to adjust benefits in the light of both positive and adverse economic conditions, and a legal guarantee. If the government wants employers to provide legal guarantees, the value of pensions would have to be reduced or, alternatively, employers would avoid guarantees altogether by a switch to DC.

\footnotetext{
'The danger is that solvency requirements that enhance security for existing DB members might perhaps bring an end to DB provision. As companies are forced to improve the funding of existing arrangements, more of them will say "that's the end".' [Pensions manager]

'The Act improves pension security for members if they are in DB. If they are not in DB the Act kills any chance of this ever being offered.' [Consultant]
} 
'There is no point in having the best regulation in the world if there are no schemes left to regulate.' [Pensions lawyer]

The unanimous view of respondents was that smaller companies, in particular, would not be able to accommodate the requirements of the Act and would be forced to close their DB schemes and to wind up as soon as possible. Some respondents, however, felt that this was an appropriate response and that DB is no longer an efficient and cost-effective benefit for most small- and medium-sized enterprises.

\section{Employers will move to DC rather than risk- sharing arrangements}

Some respondents argued that the tight timetable for deficit recovery implied by the Act would force companies to move quickly to restructure their pension arrangements and as a result risksharing approaches, such as hybrid or cash balance schemes, would not be considered.

' $D B$ is a great way to share very complex and nasty risks that most individuals are not able to deal with. The Act is forcing companies to move quickly and as a result they are going straight to DC, whereas, if they had more time, they would consider other risk-sharing structures such as career average and cash balance. Most companies have lost the opportunity to explore this middle ground.' [Asset manager]

Most respondents thought that occupational pension provision would ultimately shift to a DC basis for both new and existing employees.

'In time everyone will be in DC as schemes close to future accrual. Companies will be under pressure to do this, as to run a two-tier workforce makes no sense because DC members will demand higher salaries. It will be easier for employers to switch everyone to DC for future service.' [Consultant]

Several respondents noted that the move to DC had dangers, particularly in terms of possible under provision of pension benefits from low contribution rates. There was also concern about the implications of transferring investment and longevity risk to individual scheme members.

'Employers will have to move to DC but will do so with the nagging doubt that this is not the right way forward in the long term.' [Asset manager]
'It's unlikely DC will work - that is, provide sufficient pensions, When these chickens come hope to roost employers will face significant difficulties.' [Asset manager]

\section{Contract DC is likely to replace trust-based schemes}

Respondents thought that following the Act, many employers who close their DB arrangements will wish to avoid trust-based pension arrangements, while those with occupational DC schemes will also move to a contract basis, where the arrangement is directly between the insurance company providing the scheme and the individual employee. The apparent attraction of contract DC is that the insurance company is responsible for the governance, administration and investment functions. As the NAPF ${ }^{4}$ has, however, observed, the absence of a body responsible for looking after members' interests means that 'there is no effective mechanism to promote or represent the collective interests of scheme members'.

'Any small or medium sized company starting with a clean sheet will have to think very carefully before going down the route of occupational money purchase.' [Insurance company]

'Contract arrangements are likely to be preferred over occupational money purchase because of the administrative complexity of the latter. Even where the same requirements apply to both forms, in contract schemes the requirements can be dealt with by the provider, which has economies of scale.' [Insurance company]

\section{Conclusion}

In this paper, we have reported the views of over 70 professionals involved in the occupational pensions market in the UK about the likely implications of the Pensions Act 2004. We have found that those responsible for running the schemes - both sponsors and advisers - are deeply concerned that the Act imposes an unacceptable burden on companies providing $\mathrm{DB}$ pension schemes and risks hastening the end of DB provision as a result.

To proceed with confidence employers need the flexibility to design benefits that are appropriate to their size and financial strength, 
and which can be adjusted to reflect changing economic circumstances. Employers feel that the Pensions Act, in effect, removes much of the flexibility and raises the risks of pension provision to a level that exceeds the benefits of offering it to employees.

The government has stated in the past that it aims to shift the balance between state and private pension provision from 60:40 to 40:60 by 2050 . Occupational pension schemes arguably have a major role to play in meeting this objective, but the unintended consequence of the Act is that measures designed to shore up the occupational pensions sector seriously risk undermining it and hastening its demise. This is the Pyrrhic victory of our title.

\section{Acknowledgments}

This research was sponsored by Boots plc, Pendragon plc and Rentokil Initial plc.
The Pensions Institute is grateful for their support. The views expressed in this article are those of the authors and are not necessarily shared or endorsed by any of these companies. The full version of the Pensions Institute report 'Pyrrhic Victory? The Unintended Consequences of the Pensions Act 2004' can be downloaded free of charge from www.pensions-institute.org

\section{References and Note}

1 This paper was originally published in Economic Affairs, Vol.26, No.2, June 2006, pp. 9-16, and is reproduced here by permission of the publisher. (C) 2006 Blackwell Publishing.

2 Our original report also contains discussion of trustee board governance arrangements and the market for investment and actuarial advice and readers interested in those topics are referred to it.

3 Pensions Regulator (2005) 'Code of Practice: Funding Defined Benefits', The Pensions Regulator, Brighton.

4 NAPF (2005) 'Scheme Governance — Fit for the 21st Century', National Association of Pension Funds, London. 